\title{
Tingkat Persepsi dan Kesadaran Masyarakat Desa Tanjung Beringin Terhadap Fatwa MUI No. 04 Tentang Perlindungan Satwa Langka untuk Keseimbangan Ekosistem
}

\section{Teuku Abdul Hafizd ${ }^{1}$, Fachruddin Majeri Mangunjayaa ${ }^{1,2}$, Yeremiah R. Camin ${ }^{1}$}

1. Fakultas BiologiUniversitasNasional

2. Centre for Islamic Studies (PPI), UniversitasNasional Jl Sawo Manila Pejaten, Ps Minggu, Jakarta 12520

INDONESIA

e-mail: haf_druid90@yahoo.co.id

\section{ABSTRACT.}

Islam is a religion that covers all aspects of life, not only spirituality. It includes guidance on how humans nurture and care for the nature. Therefore Islam orders humans to manage and preserve the natural wealth and sustainably use. Conservation, meanwhile, is an effort to protect all God's creatures. The Unviversitas Nasional(UNAS) in cooperation with some Non-Governmental Organizations, push the Indonesia Ulemas Council (MUI) forward to issue a fatwa on the wildlife protection. Being an authority in religious affairs, the fatwa would serve a practical guidance on how Muslim treat the nature based on Islamic teachings. The MUI did issue the fatwa on September 2014, which is ensued by sets of training for Islamic preachers [da'i] in several places of Indonesia. One of the training was held in the Riau Province. The training was further followed by socialization of the fatwa to the community through Friday prayer speech (khutbah) by the fresh-trained preachers. Tanjung Beringin, a village adjacent to the Bukit Rimbang-Bukit Baling Wildlife Reserve, was selected to be a spot for assessment. This area is chosen for its Islamic local wisdom and its inhabitants' reliance on raw natural products. This study compared the conditions before and 
after the sermon and showed that the sermon was able to increase the people's awareness of conservation significantly $(P \leq 0,05 n=112$,) but unable to change the perception significantly $(P>0.05 n=112)$ when compared to pre-sermon. This suggests that more training and education that leads to alternative livelihood is needed - a living that does not rely on raw natural resources.

Keyword: Bukit Rimbang-Bukit Baling, Fatwa, Islam, conservation, endangered species

\section{ABSTRAK}

Islam merupakan agama yang memayungi seluruh aspek kehidupan, bukan hanya meliputi masalah spriritual, tetapi termasuk bagaimana manusia memelihara dan memperhatikan alam. Oleh karena itu Islam memerintahkan manusia mengelola dan menjaga seluruh kekayaan alam secara berkelanjutan. Konservasi, di lain pihak, merupakan upaya melindungi segala makhluk ciptaan Tuhan. Universitas Nasional bekerjasama dengan berbagai Lembaga Swadaya Masyarakat mengkaji, mempelopori, dan memohon agar Majelis Ulama Indonesia (MUI) sebagai otoritas penting yang bisa memberikan pedoman pemeliharaan alam berdasarkan Islam, mengeluarkan fatwa mengenai perlindungan satwa langka dan keseimbangan ekosistem. Selain itu, MUI bersama Pusat Pengajian Islam, Universitas Nasional menindak lanjuti fatwa tersebut dengan mengadakan pelatihan dai konservasi di berbagai daerah salah satunya berada di Propinsi Riau. Setelah pelatihan ini dilakukan, sosialisasi dilakukan kepada masyarakat melalui khutbah konservasi oleh da'i yang telah mengikuti pelatihan ke tempat asalnya. Salah satu tempat yang diamati adalah desa Tanjung Beringin, di Suaka Margasatwa (SM) Bukit RimbangBukit Baling, Riau. Daerah ini dipilih sebagai tempat penelitian karena memiliki bentuk kearifan lokal yang bercorakkan Islam dan masih bergantung hidup pada hasil alam. Penelitian ini membandingkan kondisi sebelum dan sesudah khutbah dan menunjukkan khutbah yang dilakukan mampu meningkatkan kesadaran konservasi secara signifikan $(\mathrm{P} \leq 0,05)$ namun tidak mampu mengubah persepsi jamaah secara signifikan $(\mathrm{P}>0,05 \mathrm{n}=112)$. Ini mengindikasikan kebutuhan akan pendidikan dan pelatihan yang membuat masyarakat desa tidak bergantung pada hasil alam dan mencari alternatif usaha yang berkelanjutan.

Kata kunci: Bukit Rimbang-Bukit Baling, Fatwa, Islam, Konservasi, Satwalangka 


\section{PENDAHULUAN}

Indonesia memiliki kekayaan alam hayati yang berada pada peringkat tiga terbesar dari seluruh dunia setelah Brazilia dan Kongo (Sukara dan Tobing, 2008). Darajati et al (2015) mencatat kekayaan alam hayati Fauna Indonesia terdiri dari 720 spesies Mamalia (13\% dunia), 723 spesies Reptilia (8\% dunia), 385 spesies Amphibia (6\% dunia), 1248 spesies ikan air tawar (9\% dunia), 1605 spesies Burung ( $8 \%$ dunia). Dengan jumlah kekayaan sumberdaya hayati yang melimpah tersebut Indonesia menghadapi tantangan besar untuk melestarikannya. Di lain pihak, banyak pula yang ingin memanfaatkannya sehingga berakibat banyak terjadi perburuan liar yang mengurangi populasi spesies di alam, dan akhirnya mengancam keberadaan spesies tersebut. Selain itu lahan hutan yang merupakan habitat satwa rata-rata dikonversi seluas 1,13 juta hektare per tahun untuk keperluan manusia sehingga diperlukan langkah konservasi untuk mencegah kepunahan dan hilangnya habitat dari satwa tersebut (Widjaja et al, 2014).

Berbagai cara dan upaya telah dilakukan oleh Pemerintah Indonesia untuk melindungi keanekaragaman hayati tersebut, antara lain dengan penegakan hukum dan penguatan peraturan-peraturan untuk menunjang pelestarian flora dan fauna. Indonesia telah menerbitkan UU No.05/1990 tentang konservasi Keanekaragaman Hayati dan Ekosistem sebagai dasar penegakan hukum dalam mencegah perburuan liar dan perdagangan gelap. Salah satu bentuk upaya yang dilakukan untuk menindak lanjuti peraturan tersebut adalah dengan membentuk Taman Nasional, Cagar Alam, Suaka Margasatwa, serta upaya positif lainnya untuk melindungi habitat dan ekosistem pada kawasan konservasi. Tingginya tingkat perburuan terhadap Tumbuhan dan Satwa Liar (TSL) diakibatkan rendahnya kesadaran masyarakat di perkotaan untuk mendukung upaya konservasi, misalnya dengan tidak membeli dan menjualnya (KLH, 2007).

Salah satu satwaliar yang mendapat perhatian lebih adalah Harimau Sumatera. Keberadaannya saat ini juga menjadi kebanggaan nasional karena Indonesia memiliki tiga subspesies dari delapan subspesies harimau di dunia. Hal ini tentu saja menjadikan Indonesia sebagai sorotan dunia dalam menjaga kelestarian harimau yang masih bertahan hidup di Pulau Sumatera. Populasinya kian menurun karena selain ancaman perburuan liar, juga terancam oleh perambahan hutan. Hal ini mengakibatkan banyak konflik antara manusia dengan harimau yang berujung pada pembunuhan harimau karena dinilai sebagai hama pertanian dan membahayakan manusia. Padahal manusia itu sendiri yang telah mengubah fungsi hutan yang awalnya habitat dan teritori berburu harimau menjadi berbagai lahan yang digunakan secara pribadi (LPPM-UNAS, 2013). 
Indonesia selain memiliki kekayaan sumberdaya alam hayati juga memiliki keanekaragaman budaya yang kaya dengan 336 budaya lokal, dengan beragam tingkat pendidikan penduduk yang menjalankannya. Tradisi tersebut menjadi lebih kaya dengan adanya beragam pengaruh agama dan kepercayaan yang membentuk nilai masyarakat dengan adat-istiadat di dalam menjaga alam yang disebut kearifan lokal (Mangunjaya, 2010). Proses belajar dari alam menghasilkan sebuah budaya yang diturunkan antar generasi yang mampu beradaptasi selaras dengan perubahan alam (Kehati, 2006) yang melalui proses panjang memunculkan kearifan lokal. Kearifan lokal ini dapat berbentuk aturan dalam pemanfaatan lahan untuk tempat tinggal dan penghidupan secara berkelanjutan (Fauzi, 2004) serta sebagai aturan hidup. Guna meningkatkan kesadaran akan konservasi di dalam tradisi tersebut, berbagai upaya telah dilakukan antara lain melalui kampanye yang dilakukan oleh LSM yang melaksanakan program tersebut.

Upaya konservasi yang dilakukan secara turun temurun dari generasi ke generasi, berawal dari ajaran hukum agama yang lama kelamaan menjadi kebudayaan yang berbasis pada kearifan lokal dalam menjaga alam agar dapat terus digunakan secara sukarela sekaligus menjalankan perintah agama (Mangunjaya, 2010). Penelitian pendekatan agama sebelumnya telah dilakukan oleh Clement et al (2009) di Malaysia mengenai efektivitas khutbah Jum'at untuk pemahaman tentang pelestarian penyu belimbing. Kemudian Mckay et al (2013) menerapkan metode yang sama pada saat bulan Ramadhan di pondok pesantren dan masjid dengan menyampaikan konten konservasi melalui ceramah agama sebelum shalat tarawih. Penelitian ini membuktikan pengajaran agama lebih efektif dalam meningkatkan kesadaran menjaga alam.

\section{AREA PENELITIAN}

Masyarakat Bukit Rimbang-Bukit Baling merupakan salah satu contoh masyarakat adat yang menerapkan sistem khalifah dalam pemerintahan adat dengan menjadikan nilai-nilai Islam sebagai kearifan lokal. Salah satu contoh kearifan lokal yang menjadi objek wisata adalah penerapan kawasan Lubuk Larangan. Kawasan ini tidak boleh digunakan untuk keperluan sehari-hari demi menjaga populasi ikan yang ada di sungai (Yapeka, 2015). Ia hanya boleh digunakan sebagai sarana transportasi. Selain itu juga ditetapkan hutan larangan, yaitu areal hutan yang terlarang bagi pemanfaatan apapun selian untuk melindungi harimau yang dipercaya sebagai leluhur mereka dan hewan yang dilindungi (YAPEKA, 2015).

Desa Tanjung Beringin berada di wilayah Suaka margasatwa Bukit RimbangBukit Baling, wilayah kekhalifahan Batu Sanggan. Desa ini dipilih sebagai tempat penelitian karena pada tanggal 4 hingga 8 Mei 2016 diadakan festival 
Subayang yang menarik banyak penduduk dari desa lain dan para perantau datang untuk mengikuti rangkaian festival ini, yang dimulai dengan pembukaan Lubuk larangan dan diakhiri dengan ziarah ke makam leluhur Datuk Harimau dengan membawa hadiah berupa organ dalam/viscera kerbau.

\section{METODE}

Sampling populasi dilakukan secara purposive sampling dengan menggunakan kuisioner dengan skala Likert (Allen \& Seaman, 2007). Kuisioner diberikan penomoran dan kode sebelum disebarkan kepada masyarakat. Kuisioner disebarkan kepada warga sehari sebelum khutbah Jum'at dan dicatat nomor yang diberikan. Kuisioner dibagikan kembali setelah shalat Jum'at pada sore hari kepada warga sesuai dengan penomoran kuisioner. Jawaban kuisioner ditabulasikan kedalam tabel dengan skala 1 untuk Sangat Tidak Setuju dan Tidak Setuju, serta 2 untuk Setuju dan Sangat Setuju. Setelah ditabulasikan, data dikonversikan kedalam SPSS untuk memulai analisis data. Untuk nilai poin pada instrumen nomor $1,3,6,7,8$, dan 9 yang memiliki sifat pertanyaan negatif akan ditransformasikan nilainya menjadi positif.

\section{ANALISIS DATA}

Rata-rata jawaban tiap responden akan dianalisis dengan uji T-Test berpasangan pada nilai persepsi dan kesadaran pada saat sebelum dan sesudah khutbah. Poin yang akan dianalisis berjumlah 11 buah (Lampiran Tabel 2.). Tabel 1 menunjukkan kategori dari pertanyaan yang akan dianalisis yaitu kategori persepsi dengan 8 poin (Nomor 1, 2, 3, 4, 5, 6, 7, dan 8) serta kategori kesadaran dengan 3 poin (Nomor 9, 11, dan 12). Perbandingan yang akan diambil berasal dari nilai tengah (mean) pada total jawaban yang diberikan responden pada tiap pertanyaan saat sebelum dan sesudah khutbah Jum'at pada Masjid di desa Tanjung Beringin. Hubungan antara persepsi masyarakat terhadap konservasi satwaliar dengan instrumen yang diujikan dengan menanyakan tentang hubungan kesejahteraan responden dengan satwaliar, daya tarik wisata, ancaman, manfaat, perlunya pelestarian, pemeliharaan satwa, dan gangguan satwa, sedangkan hasil kesadaran terhadap

Tabel 1. Pembagian kategori persepsi dan kesadaran.

\begin{tabular}{lc}
\multicolumn{1}{c}{ Kategori } & Item \\
Tingkat persepsi & $1,2,3,4,5,6,7,8$ \\
Tingkat kesadaran & $9,11,12$
\end{tabular}


konservasi harimau dengan instrumen pertanyaan jumlah harimau, kepedulian pemuka agama terhadap pelestarian, dan kesadaran tentang kerusakan hutan.

\section{PEMBAHASAN}

\section{A. Profil responden}

Dari 200 kuisioner yang disebar, berhasil diperoleh 112 kuisioner yang memenuhi kriteria. Syarat yang harus dipenuhi responden adalah responden harus mengisi kuisioner dengan nomor yang sama pada sebelum dan sesudah khutbah. Tingkat pendidikan responden (Gambar 2.) mayoritas SMA/MA sebanyak 46\% individu diikuti Perguruan Tinggi sebanyak 28\%, SD/MI sebanyak 14\%, SMP/MTS

Gambar 2. Tingkat pendidikan dan jenis pekerjaan responden

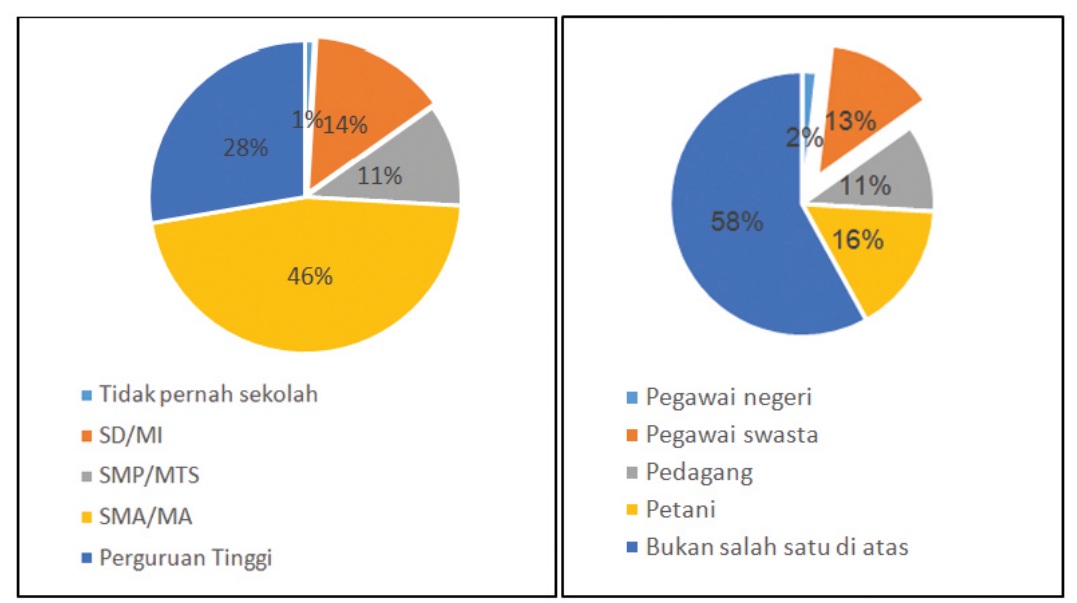

Gambar 3. Diagram umur responden

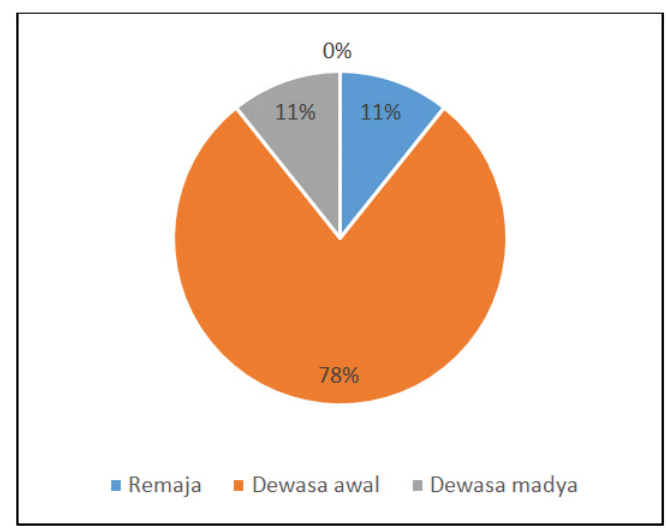


sebanyak $11 \%$, dan tidak pernah mengenyam pendidikan sekolah sebanyak $1 \%$. Mayoritas pekerjaan responden (Gambar 2.) adalah bukan salah satu di atas sebanyak $58 \%$, diikuti petani sebanyak $16 \%$, pegawai swasta $13 \%$, pedagang $11 \%$, dan pegawai negeri $2 \%$. Menurut Hurlog (2001), tingkat kedewasaan seseorang dapat dilihat dalam beberapa kategori yaitu, tingkat remaja, dewasa awal, dewasa akhir, dan dewasa lanjut. Berdasarkan pembagian kategori tersebut, responden yang masuk kedalam kategori remaja sebesar 11\%, dewasa awal 78\%, dan dewasa madya $11 \%$. Selama penelitian dijumpai responden selain penduduk asli yang menetap dan merantau, responden juga banyak yang berasal dari luar desa Tanjung Beringin yaitu daerah Lipat Kain dan beberapa desa lainnya yang menetap sementara waktu selama Festival Subayang berlangsung sebagai panitia dan pengisi acara.

\section{B. Tingkat persepsi responden}

Secara kebahasaan persepsi berarti suatu proses akhir dari pengamatan dalam mencerna dan memahami suatu masalah yang ada disekitarnya (Sunaryo, 2002). Sedangkan menurut Sternbergh 1996 (dalam Hamid, 2007) persepsi adalah suatu proses dimana kita menyimpulkan, mengorganisasi, dan memberi makna pada rangsangan yang terdapat suatu masalah di sekitar kita. Dalam konteks penelitian ini masyarakat memahami secara sadar mengenai interaksi manusia dengan satwaliar khususnya harimau. Secara keseluruhan, ketika dilakukan

Gambar 4. Perbandingan perubahan tingkat persepsi responden berdasarkan nilai mean responden pada sebelum dan sesudah khutbah

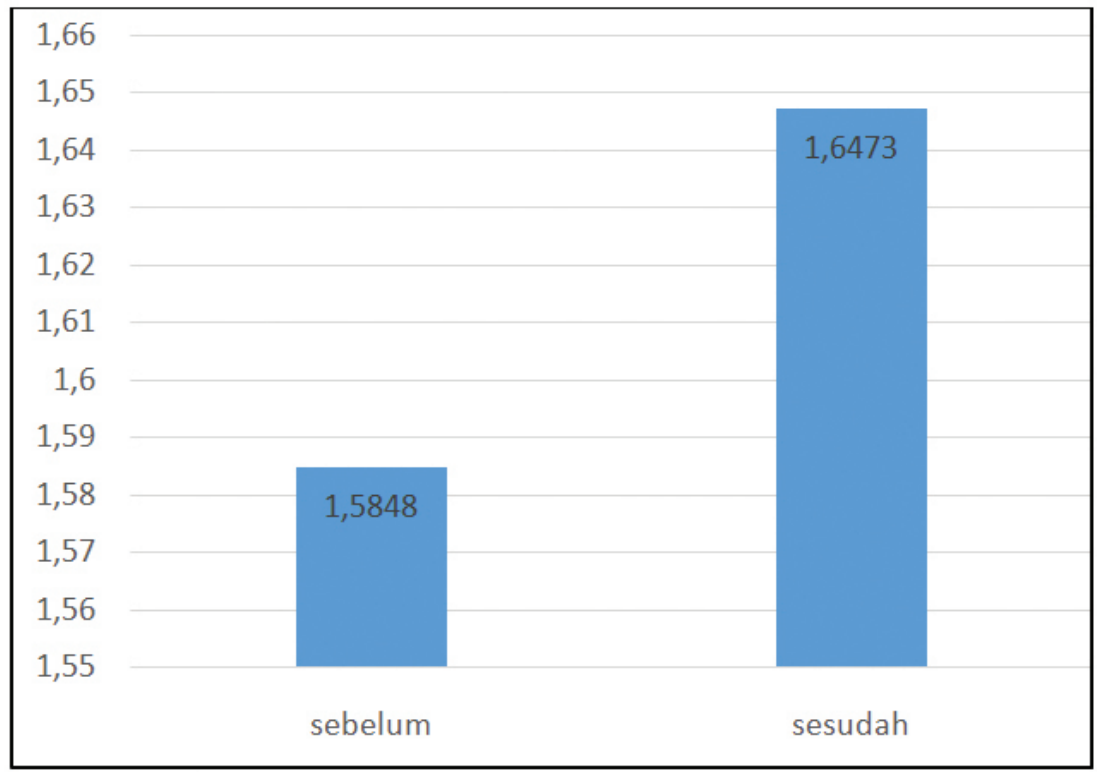


Tabel 2. Nilai mean dan total setuju (\%)tingkat persepsi responden pada sebelumdansesudah khutbah dalam instrumen persepsi $(\mathrm{n}=112)$

\begin{tabular}{|c|c|c|c|c|c|}
\hline \multirow[t]{2}{*}{ No } & \multirow[t]{2}{*}{ Pernyataan } & \multicolumn{2}{|c|}{ Mean } & \multicolumn{2}{|c|}{ Total Setuju } \\
\hline & & sebelum & sesudah & sebelum & sesudah \\
\hline 1. & $\begin{array}{l}\text { Satwaliar ada hubungannya } \\
\text { dengan kesejahteraan hidup saya }\end{array}$ & 1,69 & 1,53 & $68,8 \%$ & $52,7 \%$ \\
\hline 2. & $\begin{array}{l}\text { Satwaliar perlu dilestarikan } \\
\text { karena dapat menjadi daya tarik } \\
\text { pariwisata }\end{array}$ & 1,94 & 1,90 & $93,8 \%$ & $90,2 \%$ \\
\hline 3. & $\begin{array}{l}\text { Satwaliar seperti harimau tidak } \\
\text { berbahaya bagi manusia dan } \\
\text { ternak }\end{array}$ & 1,38 & 1,29 & $37,5 \%$ & $28,6 \%$ \\
\hline 4. & $\begin{array}{l}\text { Satwaliar bermanfaat bagi } \\
\text { kehidupan manusia }\end{array}$ & 1,76 & 1,83 & $75,9 \%$ & $83 \%$ \\
\hline 5. & $\begin{array}{l}\text { Satwaliar seperti harimau perlu } \\
\text { dilestarikan untuk generasi yang } \\
\text { akan datang }\end{array}$ & 1,85 & 1,88 & $84,8 \%$ & $87,5 \%$ \\
\hline 6. & $\begin{array}{l}\text { Satwaliar misalnya burung tidak } \\
\text { boleh dipelihara dalam kurungan } \\
\text { untuk kesenangan manusia }\end{array}$ & 1,38 & 1,64 & $37,5 \%$ & $64,3 \%$ \\
\hline 7. & $\begin{array}{l}\text { Memelihara satwaliar bukan } \\
\text { merupakan salah satu cara } \\
\text { pelestarian }\end{array}$ & 1,24 & 1,59 & $24,1 \%$ & $58,9 \%$ \\
\hline 8. & $\begin{array}{l}\text { Satwaliar yang mengganggu } \\
\text { pertanian dan ternak tidak boleh } \\
\text { dibunuh }\end{array}$ & 1,46 & 1,53 & $45,5 \%$ & $52,7 \%$ \\
\hline
\end{tabular}

penghitungan statistik diperoleh nilai mean yaitu 1,58 untuk sebelum khutbah dan 1,65 pada setelah khutbah sehingga terjadi peningkatan 0,07 antara sebelum dan sesudah khutbah. Meskipun terjadi kenaikan perbandingan jawaban responden yang menjawab setuju, nilai rata-rata jawaban responden pada kumpulan poin instrumen $1,2,3,4,5,6,7$, dan 8 untuk tingkat persepsi tidak terjadi perubahan yang signifikan (gambar 2. dan lampiran tabel 3.), dimana hasil analisis uji menurut statistik menunjukkan nilai $\mathrm{P}>0,05$ dengan jumlah responden 112 orang.

Poin instrumen no. 1 jumlah responden yang setuju bahwa satwaliar "tidak ada hubungannya dengan kesejahteraan hidup saya" menurun dari 68,8\% menjadi 52,7\% (Tabel 4 dan Lampiran Gambar 1.) yang membuktikan setelah khutbah masyarakat mempersepsikan satwaliar tidak ada hubungannya dengan mata pencaharian yang digeluti sehari-hari. Untuk persepsi negatif seperti ini, 
mereka masih merasakan bahwa keberaadaan satwaliar seperti harimau faktanya memang secara langsung belum bisa mereka rasakan. Bahkan harimau dianggap ancaman bagi ternak mereka seperti pada poin instrumen 3. (tabel 2) di mana mereka menganggap harimau adalah satwa yang berbahaya, meskipun pada poin instrumen 5. mereka setuju bahwa harimau perlu dilestarikan karena bermanfaat bagi kehidupan manusia yang meningkat dari $84 \%$ menjadi $87 \%$.

Poin instrumen no. 2, yang menanyakan bahwa satwaliar perlu dilestarikan karena dapat menjadi daya tarik pariwisata, terjadi penurunan dari 93,8\% menjadi 90.2\% (Tabel 2 dan Lampiran Gambar 2). Penilaian responden terhadap hal ini sebenarnya sudah sangat tinggi, namun setelah khutbah beberapa responden ragu atau menilai tidak semua satwaliar memiliki daya tarik pariwisata. Oleh karena itu perlu mereka menjalani bukti empiris (yang nyata) bahwa satwa dapat menjadi daya tarik dalam pariwisata. Kegiatan yang berlangsung selama penelitian seperti Festival Subayang yang diawali dengan membuka Lubuk Larangan, perlu diperkaya dengan praktek-praktek kegiatan yang berfokus pada atraksi keberadaan satwa di SM. Bukit Rimbang-Bukit Baling. Dengan demikian kegiatan ini tidak hanya bertujuan untuk menarik minat masyarakat yang berada di perantauan, tetapi juga potensi ekowisata yang berbasis pada keberadaan satwa dan alam liar didalam kawasan tersebut. Dengan demikian perlu ditingkatkan penyebaran informasi mengenai kegiatan pariwisata yang berkaitan dengan pelestarian alam dan satwaliar.

Instrumen no 3. menyatakan bahwa satwaliar seperti harimau tidak berbahaya bagi manusia dan ternak (Tabel 2 dan Lampiran gambar 3.) terjadi penurunan dari 37,3\% menjadi $28,6 \%$. Hal ini dimungkinkan akibat pengalaman konflik dengan harimau yang berbahaya bagi diri mereka maupun ternak mereka. Masyarakat merasa dirugikan oleh karena kebiasaan mereka menggembalakan ternak dan membuka hutan untuk ladang berpindah (YAPEKA, 2015).

Masyarakat desa Tanjung Beringin memandang fatwa MUI tentang satwaliar membawa manfaat bagi manusia setelah khutbah yang dibuktikan peningkatan jumlah responden yang setuju dari 75,9\% menjadi 83\% (Tabel 2 dan Lampiran gambar 4.). Selain itu responden juga menyetujui harimau perlu dilestarikan untuk generasi yang akan datang yang dibuktikan dengan kenaikan jumlah responden yang setuju dari 84,8\% menjadi 87,5\% (Tabel 2 dan Lampiran Gambar 5.). Persepsi ini membuktikan bahwa pada dasarnya responden telah mengerti bahwa satwaliar memiliki nilai penting di dalam kehidupan mereka. Selain itu adat-istiadat masyarakat yang mempercayai harimau sebagai salah satu leluhur, yang dibuktikan ziarah ke makam Datuk Harimau pada setiap pembukaan lubuk 
larangan. Kegiatan ini diawali dengan pemotongan kerbau dan pemberian organ viscera/jeroan yang ditaruh di makam sebagai wujud penghormatan (Gunawan, wawancara pribadi). Selain itu masyarakat juga mengetahui bahwa harimau dilindungi negara dan keberadaannya sangat rentan terhadap kepunahan.

Khutbah Jum'at yang disampaikan juga mampu mengubah anggapan masyarakat bahwa hewan liar seperti burung tidak boleh dipelihara untuk kesenangan, terbukti pada jumlah responden yang meningkat dari 37,55\% menjadi 64,35\% (Tabel 2 dan Lampiran gambar 6.). Masyarakat mengetahui jika burung dipelihara hanya untuk kesenangan maka populasinya akan menurun. Jumlah masyarakat yang setuju memelihara satwaliar bukan merupakan salah satu cara pelestarian naik dari 24,1\% menjadi 58,9\% (Tabel 2 dan Lampiran Gambar 7.) karena mereka mengetahui manusia dan satwaliar saling menjaga keharmonisan alam untuk menghindari konflik.

Masyarakat desa Tanjung Beringin setelah khutbah memberikan respon positif bahwa satwaliar yang mengganggu ternak tidak boleh dibunuh, dengan kenaikan 45,5\% menjadi 52,7\% (Tabel 2 dan Lampiran gambar 8.). Persepsi ini timbul dari pengetahuan bahwa satwaliar tersebut melakukan kontak dan memangsa hewan ternak karena terdesak dan hanya untuk bertahan hidup dan juga telah terjadi ketidakseimbangan di alam..

Secara keseluruhan, hal-hal yang menyebabkan tingkat persepsi masyarakat tidak signifikan antara lain adalah (1) tingkat ketergantungan masyarakat pada hasil alam yang terdapat di SM. Bukit Rimbang-Bukit Baling, (2) kurangnya sosialisasi terhadap masyarakat mengenai konservasi, (3) kesalahpahaman antara masyarakat dengan pemerintah dalam proses penetapan kawasan. Kealahfaham ini sering menimbulkan bentrokan Indrizal et al, 2010).

Kesalahpahaman yang sering terjadi salah satunya tentang perladangan berpindah, yang biasa dilakukan masyarakat sebelum dibentuknya SM. Bukit RimbangBukit Baling. Perladangan berpindah yang dilakukan masyarakat awalnya tidak bermasalah hingga mulai dicanangkannya pembentukan SM. Bukit RimbangBukit Baling pada 1982 yang menyebutkan tidak ada pemukiman di sekitar kawasan, padahal banyak terdapat desa yang berada di dalam kawasan (Indrizal et al, 2010). Kondisi ini boleh jadi mempengaruhi persepsi mereka, sehingga setelah diberikan khutbah mengenai konservasi mereka lebih bersikap antipati karena menganggap konservasi larangan menggunakan alam untuk kebutuhan hidup mereka. 
Hal ini diperburuk kurangnya komunikasi pemerintah dengan masyarakat sehingga pengetahuan masyarakat tentang upaya konservasi yang sangat minim. Selain itu, masyarakat sangat menggantungkan hidup mereka pada sumber alam yang semakin terbatas hasilnya disebabkan peraturan konservasi yang membatasi ruang gerak mereka yang berada di dalam wilayah Suaka Margasatwa.

Bagi masyarakat ini adalah sebuah dilema, karena di satu sisi mereka tahu satwaliar khususnya harimau harus dijaga, namun di sisi lain mereka mau tidak mau harus merambah hutan untuk kebutuhan pertanian dan pakan ternak (YAPEKA, 2015).

Menurut Mattaraso dan Dung (2016), faktor yang memperngaruhi pembelajaran adalah lingkungan, emosi, sosiologi, fisiologi, fisik, dan psikologi. Pada dasarnya responden dipengaruhi oleh kapasitas dalam menerima informasi di SM. Bukit Rimbang-Bukit Baling. Kapasitas menerima informasi ini dipengaruhi pula oleh faktor budaya, sehingga dorongan perubahan perilaku bisa dilakukan melalui tiga aspek (Matarasso dan Dung, 2016) yaitu: mereka harus melihat dan mengenali masalah dengan jelas, dampak yang dihadapi pada pola hidup yang sekarang, dan pemberian alternatif yang mampu memberi manfaat lebih bagi kehidupan mereka. Jika dikaitkan dengan kondisi sosial masyarakat desa Tanjung Beringin,

Gambar 5. Perbandingan perubahan tingkat kesadaran responden berdasarkan nilai mean responden pada sebelum dan sesudah khutbah

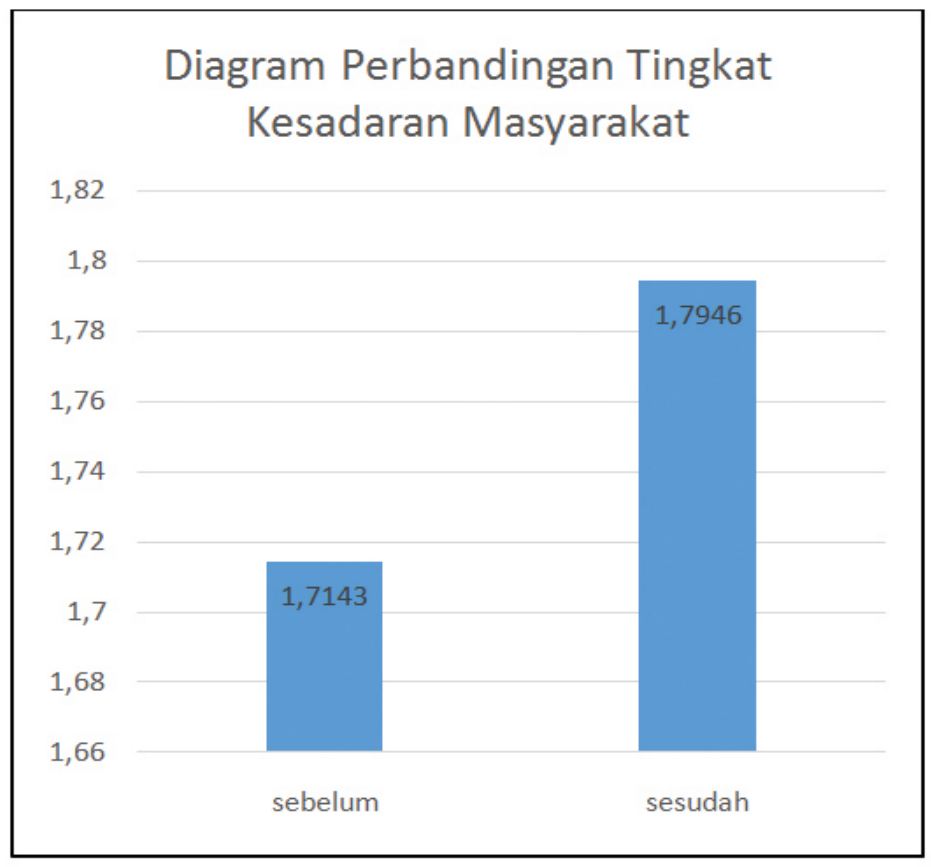


Tabel 3. Nilai mean dan total setuju (\%) tingkat kesadaran pada sebelumdansesudah khutbah dalam instrumen poin kesadaran $(n=112)$

\begin{tabular}{|c|c|c|c|c|c|}
\hline \multirow[t]{2}{*}{ No } & \multirow[t]{2}{*}{ Pernyataan } & \multicolumn{2}{|c|}{ Mean } & \multicolumn{2}{|c|}{ Total Setuju } \\
\hline & & sebelum & sesudah & sebelum & sesudah \\
\hline 1. & $\begin{array}{l}\text { Jumlah harimau saat ini relatif } \\
\text { tidak sama dengan } 10 \text { tahun lalu }\end{array}$ & 1,71 & 1,76 & $70,5 \%$ & $75,9 \%$ \\
\hline 11. & $\begin{array}{l}\text { Pemuka agama di kampung saya } \\
\text { peduli pelestarian satwaliar }\end{array}$ & 1,72 & 1,88 & $72,3 \%$ & $87,5 \%$ \\
\hline 12. & $\begin{array}{l}\text { Penebangan liar merupakan } \\
\text { sebab utama kerusakan habitat } \\
\text { satwaliar seperti harimau. }\end{array}$ & 1,71 & 1,75 & $71,4 \%$ & $75 \%$ \\
\hline
\end{tabular}

maka kondisi saat ini masyarakat sudah mampu melihat dan mengenali bahwa alam sudah tidak dapat menopang kehidupan mereka. Namun mereka menerima konsekuensi dengan tingginya risiko bencana dan menurunnya penghasilan, karena masyarakat Tanjung Beringin belum menemukan alternatif sumber penghasilan. Oleh sebab itu, mereka perlu dibantu dengan program-program penunjang yang dapat mengurangi kondisi ketergantungan tersebut pada penghasilan alternatif yang berkelanjutan.

\section{B. Tingkat kesadaran}

Secara kebahasaan kesadaran berarti kemampuan individu melakukan hubungan dengan lingkungan serta dengan dirinya sendiri melalui panca indra dan melakukan pembatasan terhadap lingkungannya melalui perhatian (Sunaryo, 2002). Dalam konteks penelitian ini masyarakat menyadari kepedulian pemuka agama terhadap pelestarian satwa liar khususnya harimau. Secara keseluruhan, ketika dilakukan penghitungan statistik diperoleh nilai mean yaitu 1,71 untuk sebelum khutbah dan 1,79 pada setelah khutbah sehingga terjadi peningkatan 0,08 antara sebelum dan sesudah khutbah. Pada hasil perhitungan uji statistik didapati terjadinya kenaikan perbandingan jawaban responden yang menjawab setuju. Nilai rata-rata jawaban responden pada kumpulan poin instrumen untuk tingkat kesadaran pada poin nomor 9,11 , dan 12 terjadi perubahan yang signifikan dengan nilai $\mathrm{P} \leq 0,05$ dengan jumlah responden 112 orang (Lampiran Tabel 4.)

Berdasarkan hasil tabulasi, pada poin instrumen 9, ditemukan jumlah warga masyarakat yang setuju bahwa jumlah harimau saat ini terlatif tidak sama dengan 10 tahun lalu meningkat dari 70,5\% menjadi 75,9\% (Tabel 3. dan Lampiran gambar 
9.). Hal ini dimungkinkan karena masyarakat yang tinggal di desa Tanjung Beringin merasakan populasi harimau tidak sama seperti 10 tahun yang lalu.

Jumlah responden yang setuju bahwa pemuka agama di kampung peduli pelestarian satwaliar naik dari 72,3\% menjadi 87,5\% (Tabel 3. dan Lampiran Gambar 10.) dikarenakan masyarakat menyadari kepedulian pemuka agama di kampungnya secara khusus desa Tanjung Beringin memiliki kepedulian yang tinggi terhadap pelestarian satwa liar melalui acara adat maupun khutbah Jum'at dan acara keagamaan lainnya.

Sedangkan masyarakat yang setuju bahwa penebangan liar merupakan sebab utama kerusakan habitat satwaliar seperti harimau naik dari 71,4\% menjadi 75\% (Tabel 3. dan Lampiran Gambar 11). Mereka menyadari penebangan hutan secara liar di hutan mengakibatkan kerusakan habitat satwaliar seperti harimau sehingga mengganggu keseimbangan alam yang berujung pada konflik harimau dengan manusia.

Secara keseluruhan, khutbah Jum'at mampu memberikan dampak langsung terhadap penyadartahuan konservasi pada masyarakat. Hal ini sejalan dengan yang dilakukan McKay et al (2013) dan Clement et al (2009) mengenai pendidikan dan penyadartahuan konservasi melalui kegiatan keagamaan seperti khutbah Jum'at yang di terapkan di Sumatera Barat dan Terengganu, Malaysia. Dengan demikian, kedepan, dapat diharapkan pendidikan dan penyadartahuan konservasi melalui kegiatan keagamaan, lebih ditingkatkan untuk memperoleh hasil yang lebih optimal.

\section{DAFTAR PUSTAKA}

Allen E \& Seaman S. 2007. Likert Scale and Data Analysis. Quality progress. Vol 40 (7) : 64-65.

Darajati W, Pratiwi S, Herwinda E, et al. 2016. Indonesian Biodiversity and Action Plan 2015-2020. Kementrian dan Perencanaan Pembangunan Nasional (Bappenas). Jakarta.

Clements R, Foo R, Othman S, et al. 2009. Islam, Turtle Conservation and Coastal Communities. Conservation Biology. Vol 23 : 516-517.

Direktorat Jenderal Planologi Hutan. 2014. Penetapan Kawasan Hutan Menuju Kawasan Hutan Indonesia yang Mantap. Direktorat Jenderal Planologi Kehutanan. Jakarta.

Fauzi A. 2004. Ekonomi Sumber Daya Alam dan Lingkungan. Teori dan Aplikasi. PT. Gramedia Utama. Jakarta. 
Gade A. 2012. Tradition and Sentiment in Indonesian Environmental Islam. Worldviews. Vol $16: 263-285$.

Gade A. 2015. Islamic Law and The Environment in Indonesia. Worldviews. Vol 19 $\therefore$ 161-183.

Google Earth. 2016. Peta wilayah Desa Tanjung Beringin. diakses 8 Desember 2016.

Hurlock, EB. 2001. Developmental Psychology: A Life Span Approach. MC Grawhill Education.

Indrizal E, Helmi, Thamrin H, et al. 2010. REDD: Antitesis Reboisasi. Scale up Sustainable Social Development Partnership. Pekanbaru.

Kementrian Lingkungan Hidup dan Kehutanan (KLHK). 2014. Renstra Dit. PJLKKHL 2010-2014. Direktorat Pemanfaatan Jasa Lingkungan Kawasan Konservasi dan Hutan Lingkungan. Kementrian Kehutanan. Jakarta.

Kementrian Negara Lingkungan Hidup. 2007. Status Lingkungan Hidup Indonesia. Kementrian Negara Lingkungan Hidup. Jakarta.

Khalid FM. 2015. Al-Qur'an, Ciptaan, dan Konservasi. Pusat Pengajian Islam (PPI) Universitas Nasional. Jakarta.

Lembaga Penelitian dan Pengabdian Masyarakat Universitas Nasional. 2013. Pelestarian Satwa Langka dalam Kearifan Islam: Inisiatif Fatwa Pelestarian Satwa langka. LPPM UNAS dengan Aliance of Religions Conservation. Jakarta.

Majelis Ulama Indonesia. 2014. Fatwa MUI No.04 Tahun 2014 Tentang Pelestarian Satwa Langka Untuk Menjaga Ekosistem. Pusat Pengajian Islam (PPI) Universitas Nasional. Jakarta.

Mangunjaya, FM. 2005. Konservasi Alam dalam Islam. Yayasan Obor Indonesia. Jakarta.

Mangunjaya FM dan Abbas AS. 2009. Khasanah alam: Menggali Tradisi Islam untuk Konservasi Alam. Yayasan Obor. Jakarta.

Mangunjaya FM. 2010. Developing Environmental Awareness And Conservation Through Islamic Teaching. Journal of Islamic Studies. Vol 22 (1): 36-49. Mangunjaya FM, Alikodra HS, Amin AA, et al. 2013. Kesadaran Lingkungan di Kalangan Santri Terhadap Pembangunan Berkelanjutan. Media Konservasi. Vol 18 (3) : 127-134.

Matarasso M \& Dung GV. Tanpa Tahun. Environmental Education: Trainer Guide for Nature Conservation. Timber for Aceh, WWF Indonesia. Jakarta. http:// d2ouvy59p0dg6k.cloudfront.net/downloads/environmental_education trainers_guide_for_nature_conservation.pdf. diakses Oktober 2016.

McKay JE, Mangunjaya FM, Dinata Y, et al. 2013. Practice What You Preach: A Faith Based Approach to Conservation in Indonesia. Oryx : 1-7. 
Purba C. 2014. Potret Keadaan Hutan Indonesia Periode 2009-2013.Forest Watch Indonesia. Bogor.

Pusat Pengajian Islam Universitas Nasional (PPI UNAS). http://ppi.unas.ac.id/ mengajak-dai-bergerak-melakukan-dakwah-konservasi-lingkungan/. Diakses 2 Mei 2016

Sternberg. 1996. Cognitive Psycology. Dalam: Meningkatkan Daya Fikir; Hamid MAA. PTS Publications and Distributors. Selangor.

Sukara E dan Tobing ISL. 2008. Industri berbasis Keanekaragaman Hayati, Masa Depan Indonesia. Vis Vitalis. Vol 01 (2) : 1-12.

Sunaryo. 2002. Psikologi Untuk Keperawatan. Penerbit Buku Kedokteran EGC. Jakarta

Syafi'i A. 2009. Revitalisasi Ushul Al-Fiqh Untuk Konservasi dan Restorasi Kosmos.

Fiqh Lingkungan: The 9th Annual Conference on Islamic Studies. Surakarta.

Syamsidar. 2013. Ulasan Singkat Valuasi Ekonomi Harimau Sumatera. WWF. Riau.

Wibisono H. 2013. Harimau Sumatera: Fungsi dan Manfaatnya. Bahan Diskusi FGD.

Widjaja EA, RahayuningsihY,Ubaidillah R, et al.2014. Kekinian Keanekaragaman Hayati Indonesia. LIPI Press. Jakarta.

Wienarto N, Pasandaran E, Hakim AL, et al. 2014. Mengintegrasikan Jasa Ekosistem dalam perencanaan Tata Ruang. Academia Edu.

World Wildlife Foundation (WWF). 2005. Peta Pulau Sumatera. assests.wwfid. panda.org/img/original/map_block_forset.jpg. diakses 8 Januari 2016.

World Wildlife Foundation (WWF). 2012. Nilai Penting Ancaman dan Masukan Untuk Pengelolaan Rimbang Baling. Riau.

World Wildlife Foundation (WWF). 2014. Peta Suaka Margasatwa Bukit Rimbang Bukit Baling. www.stripetosecure.or.id/smrbb-kekayaanalam-yang-terancam. diakses 20 Oktober 2016.

World Wildlife Foundation (WWF). 2016. Sekilas Suaka Margasatwa Rimbang Baling. Riau.

Yang AB. 2011. Islam dan Pengurusan Alam Sekitar. Dalam Ram Y, Pengurusan Alam Sekitar dan Biodiversiti dalam Perspektif Islam. Penerbit IKIM. Malaysia.

Yayasan Keanekaragaman Hayati Indonesia (KEHATI). 2006. Merekam Jejak Mitra. Pengelolaan Sumber Daya Alam Berbasis Masyarakat. Yayasan Keanekaragaman Hayati (KEHATI). Jakarta.

Yayasan Pendidikan Konservasi Alam(YAPEKA). 2015. Report in Sosioeconomic Assessment of People in and around Rimbang-Baling Wildlife Reserve. Riau. 